\title{
Biological activities of Aster scaber extracts
}

\author{
Eun-Ho Lee ${ }^{1}$, Hye-Jin Park ${ }^{1}$, Na-Hyun Kim ${ }^{1}$, Eun-Jin Hong ${ }^{1}$, Mi-Jung Park ${ }^{1}$, Seon-Ho Lee ${ }^{2}$, \\ Myung-Uk Kim ${ }^{3}$, Bong-Jeun $\mathrm{An}^{4}$, Young-Je Cho ${ }^{1 *}$ \\ ${ }^{1}$ School of Food science and Biotechnology/Food and Bio-Industry Research Institute, \\ Kyungpook National University, Daegu 41566, Korea \\ ${ }^{2}$ Department of Food Science and Technology, Yeungnam University, Gyeongsan 38541, Korea \\ ${ }^{3}$ Gyeongbuk Institute for Marin Bio-industry, UJjin 36315, Korea \\ ${ }^{4}$ Department of Cosmeceutical Science, Daegu Hanny University, Gyeongsan 38610, Korea
}

\section{참취(Aster scaber) 추출물의 생리활성}

\author{
이은호 ${ }^{1} \cdot$ 박혜진 $^{1} \cdot$ 김나현 $^{1} \cdot$ 홍은진 $^{1} \cdot$ 박미정 $^{1} \cdot$ 이선호 $^{2} \cdot$ 김명 욱 $^{3} \cdot$ 안봉전 $^{4} \cdot$ 조영제 $^{1 *}$ \\ ${ }^{1}$ 경북대학교 식품공학부/식품생물산업연구소, ${ }^{2}$ 영남대학교 식품공학과, ${ }^{3}$ 경북해양바이오산업연구원, \\ ${ }^{4}$ 대구한의대학교 화장품약리학과
}

\begin{abstract}
The phenolic compounds extracted from Aster scaber were examined for their biological activities owing to their potential use in health and beauty food products. The phenolic content in water and $60 \%$ ethanol extracts were $11.1 \pm 0.11$ and $4.18 \pm 0.05 \mathrm{mg} / \mathrm{g}$, respectively. The DPPH radical scavenging activities of the water and ethanol extracts were $87 \%$ and $91 \%$ at $50 \mu \mathrm{g}$ phenolics $/ \mathrm{mL}$, respectively. At the same phenolics concentration, the respective extracts showed $84 \%$ and $95 \%$ for ABTS radical decolorization activities and $95 \%$ and $97 \%$ for TBARs. The antioxidant protection factors for the water and ethanol extracts at $200 \mathrm{\mu g}$ phenolics $/ \mathrm{mL}$ were 1.87 and $2.22 \mathrm{PF}$, respectively. Enzyme inhibitory activities of the water and ethanol extracts $(50 \mu \mathrm{g}$ phenolics $/ \mathrm{mL})$ were $50.8 \%$ and $69.4 \%$ on angiotensin converting enzyme, $91 \%$ and $80 \%$ on xanthine oxidase, and $24 \%$ and $89 \%$ on a-amylase, respectively. The tyrosinase inhibitory activities indicating skin-whitening were $47 \%$ and $25 \%$ for the water and ethanol extracts, respectively. Anti-wrinkle effect of the water extract was relatively higher than that of the ethanol extract. These results suggest that the water and ethanol extracts of Aster scaber can be used as an ingredient in health and beauty food products.
\end{abstract}

Key words : biological activity, extracts, Aster scaber, healthy food, beauty food

\section{서 론}

최근 생활수준이 높아짐에 따라 건강에 대한 관심이 높 아지고 식생활이 개선되어지고 있다. 이에 well-being 산채 의 함유 성분에 생리활성 기능이 밝혀져 국민적 이목이

*Corresponding author. E-mail : yjcho@knu.ac.kr Phone : 82-53-950-7755, Fax : 82-53-950-7762

Received 12 October 2015; Revised 25 February 2016; Accepted 15 April 2016.

Copyright (c) The Korean Society of Food Preservation. All rights reserved.
집중되고 있으며 식품학적, 약리학적으로 가치를 새롭게 인정받고 있다(1). 현재 우리 주변에서 볼 수 있는 천연항산 화제는 Vitamin E, C류, tannin, anthocyanin, tocopherol, carotenoid류, flavonoid류 등이 있으며, 이들은 생체 내에서 노화, 고혈압, 염증, 관절염, 퇴행성질환 및 암을 예방하고 약리학적으로 아주 효과적인 것으로 보고되고 있고 $(2,3)$ 식물에서 유래된 페놀 화합물, steroid류, 비타민 등의 천연 항산화제가 활성산소 종에 의한 산화손상에 화학적 예방 촉매기능이 보고됨에 따라 많은 주목을 받아 오고 있다 (4-6). 이러한 천연물을 대상으로 성인병의 주된 원인으로 알려져 있는 활성산소 종을 억제하기위해 항산화제에 대한 다양한 연구가 수행되어지고 있고, 특히 동양의학과 대체 
의학에 대한 관심과 그 가치를 인정받으면서 민간에서 치료 및 예방을 목적으로 사용되어 지는 각종 생약이나 야생 산채류 등 약용식물을 대상으로 연구가 활발히 이루어지고 있다(7,8). 이중 산채류의 경우 일반적으로 현재 100 여종이 알려져 있고, 이 안에서는 각종 tannin, alkaloid, saponin, 배당체, flavonoids류가 많이 함유 되어 있어서 특수한 생리 학적 효과의 기능성을 나타낼 가능성이 매우 높다고 조사되 고 있다(9).

취나물은 대부분 국화과에 속한다. 취나물의 종류는 100 여 종인데 우리나라에는 분포되어 있는 것은 60 여종으로 24 종이 식용으로 가능하며, 한국에서 주로 재배되어지는 취나물은 참취(Aster scaber), 각시취(Saussurea pulchella), 곰취(Ligularia fischer), 곤달비(Ligularia stenocephala) 등 이 있다(10). 이 중에서 참취(Aster scaber)는 쌍떡잎식물 합판화군 초롱꽃목 국화과의 다년초로서 지역에 따라 나물 취, 암취, 향소, 동풍채라고도 불리며, 전국의 산지와 들의 초원에서 자라는 취의 일종으로 뿌리잎은 가장자리에 굵은 톱니가 있고 자루가 길고 심장 모양으로 꽃이 필 때쯤에 없어지고, 어린순은 취나물이라 하고 생식하거나 가열 처 리한 나물로 섭취하였으며, 건조한 후 수시로 나물의 원료 로 사용하였고 맛은 대체로 향긋하고 쌉쌀한 특징을 가지고 있다 $(11,12)$. 예로부터 동의학사전에서는 황달, 간염, 해독 제거, 혈액순환 촉진, 진통작용, 해소, 소화 장애, 타박상, 장염으로 인한 복통, 풍 제거, 골절의 동통치료에 효능이 있는 것으로 알려져 왔다(13). 한방에서는 진통, 해독의 치 료에 뿌리를 약재로 쓰며, 예부터 인후염, 요통, 두통, 근골 통증, 장염으로 인한 복통 등의 치료에 효과가 있는 것으로 알려져 있다(11). 참취에는 $\mathrm{Ca}, \mathrm{Fe}$ 및 $\beta$-carotene 등이 함유 되어 있으며(11), 약용성분으로는 옹근풀의 경우 다량의 flavonoid 화합물과 saponin을 함유하고 있고, 꽃 이삭과 줄기에는 정유 성분이, 뿌리에는 coumarin, sapogenin, shionon, alkaloid, squalene, friedelin, a-spinasterol 등의 기능 성 성분을 함유하고 있는 것으로 알려지고 있다(14). 또한 참취의 생리활성 연구는 지방대사와 항산화에 미치는 영향 (9), 고지혈증 예방효과와 혈중 콜레스테롤 LDL, VLDL 농도의 저하 및 혈관 내피세포의 변화 지연(15), HMG-CoA reductase 저해활성(16)등이 보고되었다.

사람은 사이가 들어감(aging)에 따라 신체적으로 여러가 지 현상들이 나타나게 된다. 고혈압, 당뇨, 관절염 등 성인병 의 발현과 피부색이 어두워지고 주름이 생기는 등의 피부외 적인 변화를 겪게 된다. 본 연구에서는 참취로부터 phenolic compounds를 추출하여 이러한 노화에 따른 여러 가지 징후 에 대한 anti-aging 효과를 비교, 검토하여 참취 추출물을 성인병예방식품 및 기능성 미용식품 소재로 개발 가능성을 검증하고자 하였다.

\section{재료 및 방법}

실험재료

본 연구에서 사용된 참취(Aster scaber)는 시중에서 생채 를 구입하여 $45^{\circ} \mathrm{C}$ dry oven(Jeiotech, Daejeon, Korea)에서 건조시킨 후 $40 \mathrm{mesh}$ 로 분쇄하여 시료로 사용하였다.

\section{참취 추출물의 제조}

생리활성 측정을 위한 추출물의 제조는 물 추출물의 경 우 참취 분말 $1 \mathrm{~g}$ 을 증류수 $200 \mathrm{~mL}$ 에 침지하여 추출물이 $100 \mathrm{~mL}$ 가 될 때까지 가열한 후 냉각하여 24시간 동안 교반 추출하였으며, ethanol 추출물은 참취 분말 $1 \mathrm{~g}$ 에 $60 \%$ ethanol $100 \mathrm{~mL}$ 를 첨가하여 $4^{\circ} \mathrm{C}$ 의 shaking incubator에서 24시간 동안 교반 추출하였다. 각 추출물은 Whatman No. 1 filter paper(Whatman, piscataway, NJ, USA)로 여과한 후 필요에 따라 rotary vacuum evaporator(Eyela $\mathrm{NE}$, Tokyo, Japan)에서 농축하여 시료로 사용하였다.

\section{Total phenolic 정량}

Total phenolic 정량은 추출물 $1 \mathrm{~mL}$ 에 $95 \%$ ethanol $1 \mathrm{~mL}$ 와 증류수 $5 \mathrm{~mL}$ 를 첨가하고 $1 \mathrm{~N}$ Folin-ciocalteu reagent 0.5 $\mathrm{mL}$ 를 잘 섞어 5 분간 방치한 후 $\mathrm{Na}_{2} \mathrm{CO}_{3} 1 \mathrm{~mL}$ 를 가하여 흡광도 $725 \mathrm{~nm}$ 에서 1시간 이내에 측정하여 gallic acid를 이용한 표준곡선으로부터 양을 환산하였다(17).

\section{항산화 효과 측정}

1,1-diphenyl-2-picrylhydrazyl(DPPH) radical에 대한 소거 활성은 Blios의 방법(18)에 준하여 측정하였으며, 전자공여 능(\%)은 1-(반응구의 흡광도/대조구의 흡광도) $\times 100$ 으로 나 타내었다. 2,2'-Azinobis-(3-ethylbenzothiazoline-6-sulfonic acid) radical cation decolorization(ABTS)의 측정은 Pellegrin 등의 방법(19)에 준하여 측정하였고, 저해율(\%)은 1-(반응 구의 흡광도/대조구의 흡광도) $\times 100$ 으로 나타내었다. Antioxidant protection factor(PF)는 Andarwulan과 Shetty의 방법(20)에 준하여 측정하였으며, $\mathrm{PF}$ 는 반응구의 흡광도/ 대조구의 비로 나타내었다. Thiobarbituric acid reactive substance(TBARs) 측정은 Buege와 Aust의 방법(21)에 준하 여 측정하여 저해율(\%)은 1-(반응구의 TBARs $\mu \mathrm{M} /$ 대조구 의 TBARs $\mu \mathrm{M}) \times 100$ 으로 나타내었다.

Angiotensin converting enzyme(ACE) 저해효과 측정

$\mathrm{ACE}$ 저해효과 측정은 Cushman과 Cheung의 방법(22)에 준하여 측정하였다. 반응구는 $0.3 \mathrm{M} \mathrm{NaCl}$ 을 함유한 0.1 $\mathrm{M}$ potassium phosphate buffer(pH 8.3)에 녹인 기질액 2.5 mM hippuryl-L-histidyl-L-leucine(HHL, Sigma-Aldrich Co, Louis, MO, USA) $0.15 \mathrm{~mL}$ 와 ACE(Sigma-Aldrich Co, St. Louis, MO, USA, 0.25 unit $/ \mathrm{mL}) 0.1 \mathrm{~mL}$ 와 시료 $0.1 \mathrm{~mL}$ 을 
넣고, 대조구에는 시료 대신 증류수를 $0.1 \mathrm{~mL}$ 를 첨가하여 $37^{\circ} \mathrm{C}$ 에서 30 분간 반응시킨 후 종료시약 $1 \mathrm{~N} \mathrm{HCl} 0.25 \mathrm{~mL}$ 를 가하고 ethyl acetate $3 \mathrm{~mL}$ 을 첨가하였다. Ethyl acetate에 의해 분리된 이중층 중 상층액만 분취하여 증류 건조시켜 hippuric acid를 추출하고, 추출된 hippuric acid를 $2 \mathrm{~mL}$ 의 증류수를 사용하여 재용해하여 흡광도 $280 \mathrm{~nm}$ 에서 측정하 였다. ACE 저해율(\%)은 (1-시료의 hippuric acid 함량/대조 구의 hippuric acid 함량 $) \times 100$ 으로 계산하였다.

\section{Xanthine oxidase(XOase) 저해효과 측정}

Xanthine oxidase 저해효과 측정은 Stirpe와 Della Corte의 방법(23)에 준하여 측정하였다. 즉, 반응구는 $0.1 \mathrm{M}$ potassium phosphate buffer( $\mathrm{pH}$ 7.5)에 녹인 기질액 $2 \mathrm{mM}$ xanthine $3 \mathrm{~mL}$ 에 효소액 $(0.05 \mathrm{U} / 0.1 \mathrm{~mL}) 0.1 \mathrm{~mL}$ 와 시료 $0.3 \mathrm{~mL}$ 를 넣고 대조구에는 시료 대신 증류수를 $0.3 \mathrm{~mL}$ 첨가하여 $37^{\circ} \mathrm{C}$ 에서 5 분간 반응시키고 종료시약 $20 \% \mathrm{TCA}$ $1 \mathrm{~mL}$ 를 가한 후 반응액을 원심분리하여 단백질을 제거하고 생성된 uric acid를 흡광도 $292 \mathrm{~nm}$ 에서 측정하여, 저해율(\%) 은 (1-시료의 uric acid 함량/대조구의 uric acid 함량) $\times 100$ 으 로 계산하였다.

\section{Pancreatin a-amylase 저해효과 측정}

Pancreatin a-amylase 저해 효과 측정은 agar diffusion 방 법(24)에 준하여 측정하였다. Plate는 $5 \mathrm{~g}$ 의 agar와 $5 \mathrm{~g}$ 의 soluble starch를 증류수에 녹여 꼻인 후, $121^{\circ} \mathrm{C}$ 로 15 분간 멸균하고 $15 \mathrm{~mL}$ 씩 petridish에 붓고 굳혀 제작하여 사용하 였다. 제작한 plate에 지름 $10 \mathrm{~mm}$ disc paper를 올린 후 시료 액 $0.8 \mathrm{~mL}$ 와 효소액 $0.2 \mathrm{~mL}(1,000 \mathrm{U} / \mathrm{mL})$ 를 혼합해 disc paper에 각각 분주하고 대조구에는 시료액 대신 증류수를 넣어 $37^{\circ} \mathrm{C}$ 에서 3 일간 배양한 후 $\mathrm{I}_{2} / \mathrm{KI}\left(5 \mathrm{mM} \mathrm{I}_{2}\right.$ in $\left.3 \% \mathrm{KI}\right)$ $3 \mathrm{~mL}$ 를 가하여 15 분간 발색시킨 후 다음의 식으로 저해율 (\%)은 (1-시료의 clear zone area/대조구의 clear zone area) $\times 100$ 으로 계산하였다.

\section{Tyrosinase 저해효과 측정}

Tyrosinase 저해효과 측정은 Hearing의 방법(25)에 준하 여 측정하였다. 반응구는 $0.1 \mathrm{M}$ sodium phosphate buffer( $\mathrm{pH}$ 6.8) $2.3 \mathrm{~mL}$ 와 기질액 $1.5 \mathrm{mM}$ L-tyrosine 용액 $0.4 \mathrm{~mL}$ 의 혼합액에 mushroom tyrosinase(Sigma-Aldrich Co., St. Louis, MO, USA, $250 \mathrm{U} / \mathrm{mL}) 0.1 \mathrm{~mL}$ 와 시료 $0.2 \mathrm{~mL}$ 를 넣고 대조구에는 시료 대신 증류수를 $0.2 \mathrm{~mL}$ 를 첨가하여 $37^{\circ} \mathrm{C}$ 에 서 20 분간 반응시켜 흡광도 $475 \mathrm{~nm}$ 에서 측정하여, 저해율 (\%)은 (1-시료의 absorbance/대조구의 absorbance) $\times 100$ 으 로 계산하였다.

\section{Elastase 저해효과 측정}

Elastase 저해효과 측정은 James 등의 방법(26)에 준하여
측정하였다. 반응구는 $0.2 \mathrm{M}$ Tris- $\mathrm{HCl}$ buffer(pH 8.0) $1 \mathrm{~mL}$ 에 기질액 $0.8 \mathrm{mM} \mathrm{N}$-succinyl-(Ala) 3 -p-nitroanilide 용액 0.1 $\mathrm{mL}$ 의 혼합액에 $1.0 \mathrm{U} / \mathrm{mL}$ porcine pancreatice elastase (PPE)(Sigma-Aldrich Co., St. Louis, MO, USA) 효소용액 $0.1 \mathrm{~mL}$ 와 시료 $0.1 \mathrm{~mL}$ 를 넣고 대조구에는 시료 대신 증류수 $0.1 \mathrm{~mL}$ 를 첨가하여 $25^{\circ} \mathrm{C}$ 에서 20 분간 반응시켜 $\rho$ -nitroaniline 생성량을 흡광도 $410 \mathrm{~nm}$ 에서 측정하여 저해율 (\%)은 (1-시료의 absorbance/대조구의 absorbance) $\times 100$ 으 로 계산하였다.

\section{통계처리}

실험결과의 통계분석은 SAS(Statistical Analysis System, SAS Institute Inc., Cary, NC, USA) 프로그램을 이용하여 통계처리 하였고 Duncan의 다중범위검정법(Duncan's multiple range test)으로 유의성을 검정하였다.

\section{결과 및 고찰}

용매 종류, 용매농도 및 용출시간이 phenolic 화합물의 용 출에 미치는 영향

참취 추출물의 고형분에 함유된 phenol성 화합물들의 함량은 Fig. $1 \mathrm{~A}$ 에서와 같이 $12 \mu \mathrm{g} / \mathrm{solid} 1 \mathrm{mg}$ 정도의 매우 낮은 함량을 나타내었으며, phenolic 화합물 함량이 낮은 고형분의 생리활성 역시 동량의 phenolic화합물에 비해 매 우 낮은 수준으로 나타났다(Fig. 1B). 따라서 참취 추출물이 나타내는 생리활성은 추출물에 함유되어있는 phenolic 화 합물에 의해 효과가 좌우될 것으로 판단되었다. 앞의 결과 에 근거하여 참취로부터 생리활성에 관여하는 phenolic 화 합물을 추출하기 위하여 phenolic을 보다 효율적으로 추출 할 방안을 확립하기 위하여 인체에 유해하지 않은 용매로 물과 에탄올을 선택하여 추출 시간, 용매의 농도에 따라 추출되는 phenolic 화합물의 함량을 측정하였다.

과실과 채소에 함유되어 있는 phenol성 물질들, flavonoid 등의 물질들은 유해한 활성산소종에 대해 보호 작용이 있는 다수의 항산화물질을 함유하고 있고, 항산화, 항염, 항암 등의 만성질환에 유효한 효과를 나타내는 것으로 보고되어 있다 $(27,28)$. 따라서 ethanol을 다양한 농도로 사용하여 추 출하여 phenolic의 함량을 측정한 결과 Fig. $1 \mathrm{C}$ 에서와 같이 물추출물이 phenolic의 함량이 가장 높게 나타났으며, ethanol은 농도 간 유의적 차이를 거의 나타내지 않았다. 이러한 결과는 phenol성 물질의 용출에 미치는 polarity의 차이에 기인한 것으로 추측되며 향후 검토해 보아야 할 사항으로 생각되었다. 상대적으로 $60 \%$ ethanol을 추출 용매 로 사용한 실험군의 phenolic 함량이 다른 농도의 추출물에 비해 상대적으로 다소 높게 나타나 향후 실험에서는 물추출 물과 $60 \%$ ethanol 추출물을 연구시료로 이용하였다. Phenolic 

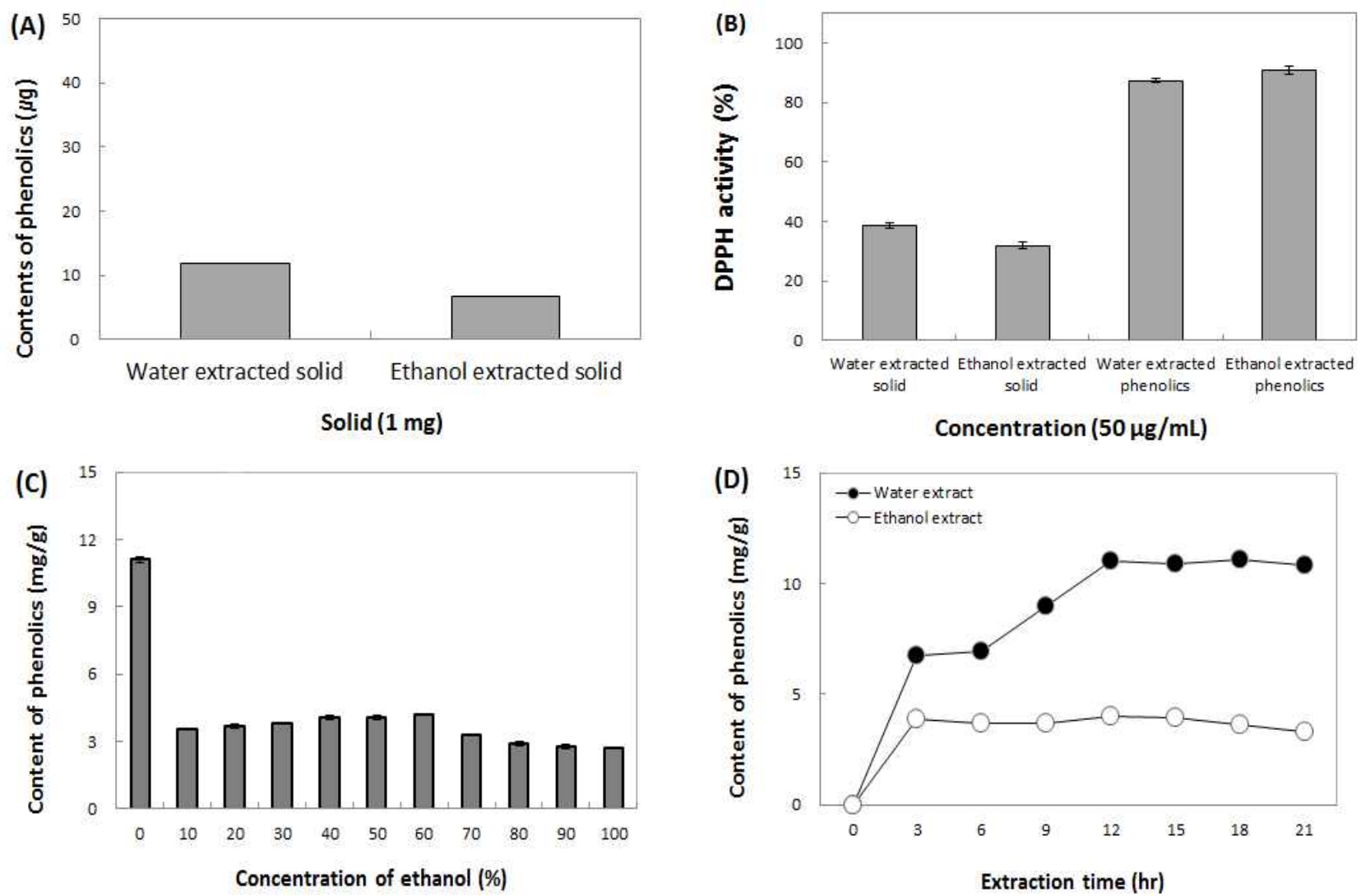

Fig. 1. The effect of extracted in solid (A), DPPH of solid and phenolic (B), ethanol concentration (C) and extraction time (D) on extraction of phenolic from Aster scaber.

The data were expressed as the mean $\pm S D(n=6)$.

성 화합물의 추출을 위한 최적 추출 시간은 Fig. $1 \mathrm{D}$ 에서와 같이 물 추출물이 12 시간, $60 \%$ ethanol 추출물이 3시간에서 높은 용출량을 나타내었다. 위의 결과에 따라 생리활성 효 과에 대한 기능성 탐색을 위하여 참취 추출물을 건강기능성 식품에 적용하기 위해 물과 $60 \%$ ethanol 추출물을 용매로 사용하여 각각 15 시간과 3 시간 동안 추출 후 생리활성 효과 를 측정하였다.

\section{참취 추출물의 항산화 효과}

$\mathrm{DPPH}$ radical법은 일종의 전자공여능을 측정하는 방법 으로 DPPH는 불안정한 상태로 있는 hydrazyl의 질소원자 가 쉽게 수소원자를 받아들이는 성질을 가지고 있어 항산화 성 물질과 반응하여 수소원자를 받아들여서 자체의 정색성 을 잃게 되는 성질을 이용하여 항산화능의 정도를 측정할 수 있게된다(29). 참취 추출물을 이용하여 전자공여능을 측정한 결과 Table 1 에서와 같이 $50 ~ 200 \mu \mathrm{gg} / \mathrm{mL}$ 의 phenolic 화합물 농도 범위에서 대조구인 BHT는 $51.83 \sim 75.88 \%$ 의 전자공여능을 나타내었으나, 물 추출물의 경우 87.47 $90.62 \%$ 의 전자공여능을, ethanol 추출물에서 90.71 93.13\% 의 전자공여능을 나타내었다. 물추출물이 ethanol 추출물에 비해 상대적으로 phenol성 화합물의 함량이 높으나 항산화
측정을 위한 시료 제조시 phenol 함량을 50 200 $\mathrm{\mu g} / \mathrm{mL}$ 으로 동일하게 조절한 결과 물추출물과 ethanol 추출물의 전자공 여능이 비슷한 결과를 나타낸 것으로 판단되며, ethanol 추 출물이 물추출물보다 상대적으로 전자공여능이 다소 높게 나타난 것은 각 추출물에 함유되어있는 phenolic의 profile 이 다르기 때문으로 추측되었다. Kim 등(30)은 하고초 (Prunella vulgaris) 추출물의 항산화 측정 결과, 열수 추출물 과 ethanol 추출물에서 각각 $79 \%, 75 \%$ 의 전자공여능을 나 타낸다고 보고한 것과 비교하면 참취 추출물의 전자공여능 이 더 우수한 효능을 가진 것을 알 수 있었다. 혈장에서 $\mathrm{ABTS}$ 는 metmyoglobin이 과산화수소에 의해 활성화 되어 $\mathrm{ABTS}^{+}$을 형성한다. $\mathrm{ABTS}$ assay는 $\mathrm{ABTS}$ 와 potassium persulfate와 반응하여 파랑/녹색의 $\mathrm{ABTS}^{+}$을 형성하고 항산 화제 존재 시 $\mathrm{ABTS}^{+}$이 소거되는 정도를 분석하는 방법 (31-33)으로 ABTS를 측정한 결과 Table 1에서와 같이 대조 구인 BHT는 $200 \mathrm{\mu g} / \mathrm{mL}$ 에서 $85.53 \%$ 의 ABTS저해능을 나타 내었으나, 참취 추출물은 물 추출물과 ethanol 추출물 모두 저 농도의 $50 \mathrm{\mu g} / \mathrm{mL}$ 에서 $99.0,98.8 \%$ 의 높은 활성을 나타내 었다. 이러한 결과로 보아 참취 추출물은 수용성 항산화제 인 vitamin $\mathrm{C}$ 와 같이 수용성 부분에서 활성산소와 반응하여 이를 불활성화 시키고, 수용액상에서 +3 가 철분 $\left(\mathrm{Fe}^{3+}\right)$ 을 
Table 1. Antioxidant activity of extracts from Aster scaber

\begin{tabular}{|c|c|c|c|c|c|}
\hline \multirow{3}{*}{ Type } & \multirow{3}{*}{ Sample } & \multicolumn{4}{|c|}{ Antioxidant activity (\%) } \\
\hline & & \multicolumn{4}{|c|}{ Phenolic content $(\mu \mathrm{g} / \mathrm{mL})$} \\
\hline & & 50 & 100 & 150 & 200 \\
\hline \multirow{3}{*}{ DPPH } & Water extracts & $87.47 \pm 0.56^{\mathrm{al})}$ & $89.69 \pm 0.28^{\mathrm{ab}}$ & $88.39 \pm 1.53^{\mathrm{ab}}$ & $90.62 \pm 1.16^{b}$ \\
\hline & Ethanol extracts & $90.71 \pm 1.37^{\mathrm{bc}}$ & $87.37 \pm 1.32^{\mathrm{a}}$ & $90.25 \pm 3.28^{b}$ & $93.13 \pm 1.68^{\mathrm{c}}$ \\
\hline & BHT & $51.83 \pm 0.40^{\mathrm{a}}$ & $67.20 \pm 0.13^{b}$ & $73.14 \pm 0.35^{\mathrm{c}}$ & $75.88 \pm 0.48^{d}$ \\
\hline \multirow{3}{*}{ ABTS } & Water extracts & $99.02 \pm 0.36^{b}$ & $99.23 \pm 0.15^{b}$ & $98.46 \pm 0.41^{\mathrm{ab}}$ & $98.05 \pm 0.18^{\mathrm{a}}$ \\
\hline & Ethanol extracts & $98.82 \pm 0.32^{\mathrm{a}}$ & $98.82 \pm 0.09^{\mathrm{a}}$ & $98.11 \pm 0.18^{\mathrm{a}}$ & $98.31 \pm 0.15^{\mathrm{a}}$ \\
\hline & BHT & $4.54 \pm 1.21^{\mathrm{a}}$ & $64.12 \pm 0.48^{b}$ & $82.29 \pm 0.68^{c}$ & $85.53 \pm 0.82^{c}$ \\
\hline \multirow{3}{*}{$\begin{array}{l}\text { Antioxidant protection } \\
\text { factor }\end{array}$} & Water extracts & $1.14 \pm 0.05^{\mathrm{a}}$ & $1.49 \pm 0.07^{b}$ & $1.51 \pm 0.12^{\mathrm{b}}$ & $1.87 \pm 0.02^{\mathrm{c}}$ \\
\hline & Ethanol extracts & $1.28 \pm 0.03^{\mathrm{a}}$ & $1.59 \pm 0.03^{\mathrm{b}}$ & $1.93 \pm 0.09^{\mathrm{c}}$ & $2.22 \pm 0.03^{\mathrm{d}}$ \\
\hline & BHT & $1.92 \pm 0.01^{\mathrm{a}}$ & $2.18 \pm 0.01^{b}$ & $2.31 \pm 0.01^{\mathrm{c}}$ & $2.46 \pm 0.03^{\mathrm{d}}$ \\
\hline \multirow{3}{*}{ TBARs } & Water extracts & $95.10 \pm 0.20^{b}$ & $96.74 \pm 0.10^{\mathrm{bc}}$ & $97.28 \pm 0.35^{\mathrm{c}}$ & $93.56 \pm 0.27^{\mathrm{a}}$ \\
\hline & Ethanol extracts & $96.65 \pm 0.98^{\mathrm{a}}$ & $99.95 \pm 1.78^{b}$ & $99.96 \pm 0.98^{b}$ & $99.95 \pm 4.42^{\mathrm{b}}$ \\
\hline & BHT & $97.77 \pm 0.31^{\mathrm{a}}$ & $97.30 \pm 0.72^{\mathrm{a}}$ & $97.36 \pm 0.96^{\mathrm{a}}$ & $97.66 \pm 0.72^{\mathrm{a}}$ \\
\hline
\end{tabular}

${ }^{1)} \mathrm{Mean} \pm \mathrm{SD}(\mathrm{n}=6)$, means with different superscript letters within level are significantly different at $\mathrm{p}<0.05$ by Duncan's multiple range tests. BHT was used for control.

+2 가 철분 $\left(\mathrm{Fe}^{2+}\right)$ 으로 환원시켜 지방질을 과산화 시키는 효 소인 lipoxygenase의 활성을 저하시켜 준 것을 알 수 있었다. 참취 추출물의 antioxidant protection factor의 차이를 측정한 결과 Table 1에서와 같이 대조구인 BHT는 1.92 2.46 PF를 나타내었으나, 물 추출물의 경우 1.14 1.87 PF를, ethanol 추출물은 1.28 2.22 PF의 항산화능을 나타내어 대조구인 BHT와 유사한 효능을 나타내는 것으로 확인되었다. 참취 추출물의 thiobarbituric acid reactive substance를 측정한 결 과 Table 1에서와 같이 대조구인 BHT는 97.77 97.66\%의 높은 항산화력을 나타내었고, 물 추출물과 ethanol 추출물 도 $50 \mathrm{\mu g} / \mathrm{mL}$ 의 저농도에서 각각 $95.1 \%, 96.7 \%$ 의 높은 저해 력을 나타내어 지용성 물질에 대한 항산화력도 매우 높은 것을 확인할 수 있었다. 위의 결과로 보아 참취 추출물은 수용성 및, 지용성 항산화에 높은 효능을 나타내었고, 추출 물의 phenolic 화합물에 농도 의존적인 양상 효과를 나타내 는 것으로 확인되었다.

참취 추출물의 angiotensin converting enzyme(ACE) 효과

Angiotensin converting enzyme(ACE)은 renin에 의하여 생성된 angiotensin I으로부터 C-말단 dipeptide(His-Leu)를 가수분해 시킴으로서 강력한 혈관수축작용을 나타내는 angiotensin II를 생성하여 고혈압의 원인이 되고 있다(34). 참취 추출물의 $\mathrm{ACE}$ 저해 활성을 측정한 결과 Table 2에서 와 같이 ethanol 추출물이 물 추출물에 비해 저해율이 상대 적으로 높게 나타났으며, 50 200 $\mathrm{\mu g} / \mathrm{mL}$ 의 phenolics 농도 범위의 물 추출물에서 $28.0 ~ 50.8 \%$ 의 저해율을 나타내었고, ethanol 추출물에서 60.8 69.4\%의 $\mathrm{ACE}$ 저해율을 나타내어, 혈압약으로 쓰이고 있는 Captopril과 유사한 $\mathrm{ACE}$ 저해 효과
를 나타내었다. Jo와 Cho(35)는 오가피 열매(Acanthopanax fruit) 추출물의 phenolic 화합물이 $200 \mu \mathrm{g} / \mathrm{mL}$ 의 phenolics 농도에서 물 추출물과 ethanol 추출물이 $59.5,85.1 \%$ 의 $\mathrm{ACE}$ 억제력을 나타내었다고 보고한 것과 비교해 참취 추출물의 고혈압억제력이 비슷한 것으로 판단되어, 향후 renin angiotensin system에 의한 고혈압억제를 위한 예방 또는 치료기능을 활용한 기능성 식품 등에 활용할 수 있을 것이 라 판단되었다.

\section{참취 추출물의 xanthine oxidase 효과}

Xanthine oxidase(XOase)는 purine 대사에 관여하는 효소 로서 xanthine 또는 hypoxanthine의 산소를 때어내면서 과산 화수소 $\left(\mathrm{H}_{2} \mathrm{O}_{2}\right)$ 를 생성하게 되고, 나머지 골격이 uric acid를 형성하여 혈장 내에 과량 존재하게 되면 신장에 침착되어 신장질환을 일으키고, 골절에 축적되어 심한 통증을 유발 하는 통풍 효소로 알려져 있다(34). XOase 저해활성 측정은 대조구로 allopurinol을 사용하였으며 참취 추출물과 농도 별로 비교하였다. 참취 추출물의 XOase 저해 활성을 측정 한 결과 Table 3에서와 같이 물 추출물이 ethanol 추출물에 비해 저해율이 상대적으로 높게 나타났으며, $50 ~ 200 \mu \mathrm{g} / \mathrm{mL}$ 의 phenolics 농도 범위의 물 추출물에서 90.9 93.9\%의 저해 율을 나타내었고, ethanol 추출물에서 21.9 80.2\%의 XOase 저해율을 나타내어, 참취 물 추출물은 저 농도에서도 통풍 억제약제인 allopurinol보다 더 우수한 XOase 저해효과를 나타내었다. Kim 등(36)은 유근피(Ulmus pumila) 추출물의 phenolic 화합물이 $200 \mathrm{\mu g} / \mathrm{mL}$ 의 phenolics 농도에서 $48.1 \%$ 의 XOase 억제력을 나타내었다고 보고한 것에 비해 참취 추출물의 통풍억제력이 더 우수하여 통풍 치료제로서 활용 
Table 2. Inhibition activity of extracts from Aster scaber on angiotensin converting enzyme

\begin{tabular}{|c|c|c|c|c|c|c|}
\hline \multirow{3}{*}{$\begin{array}{l}\text { Phenolic concent } \\
\quad(\mu \mathrm{g} / \mathrm{mL})\end{array}$} & \multicolumn{6}{|c|}{ Sample } \\
\hline & \multicolumn{2}{|c|}{ Water extracts } & \multicolumn{2}{|c|}{ Ethanol extracts } & \multicolumn{2}{|c|}{ Captopril } \\
\hline & Hippuric acid $(\mu \mathrm{g} / \mathrm{mL})$ & Inhibition activity (\%) & Hippuric acid $(\mu \mathrm{g} / \mathrm{mL})$ & Inhibition activity (\%) & Hippuric acid $(\mu \mathrm{g} / \mathrm{mL})$ & Inhibition activity (\%) \\
\hline Control & $204.70 \pm 1.05^{1)}$ & - & $213.70 \pm 0.87$ & - & $221.70 \pm 0.98$ & - \\
\hline 50 & $153.67 \pm 1.53$ & $27.98 \pm 0.72^{\mathrm{a}}$ & $83.67 \pm 4.62$ & $60.79 \pm 2.16^{\mathrm{a}}$ & $105.00 \pm 1.00$ & $50.79 \pm 0.47^{\mathrm{a}}$ \\
\hline 100 & $131.33 \pm 4.16$ & $38.45 \pm 1.95^{\mathrm{b}}$ & $81.00 \pm 4.00$ & $62.04 \pm 1.87^{a}$ & $98.00 \pm 7.00$ & $54.07 \pm 3.28^{\mathrm{a}}$ \\
\hline 150 & $120.67 \pm 5.03$ & $43.45 \pm 2.36^{\mathrm{c}}$ & $69.00 \pm 2.00$ & $67.66 \pm 0.94^{b}$ & $77.00 \pm 2.65$ & $63.91 \pm 1.24^{\mathrm{b}}$ \\
\hline 200 & $105.00 \pm 5.29$ & $50.79 \pm 2.48^{d}$ & $67.67 \pm 0.58$ & $69.38 \pm 0.27^{c}$ & $53.00 \pm 1.00$ & $75.16 \pm 0.47^{\mathrm{c}}$ \\
\hline
\end{tabular}

${ }^{1)}$ Mean \pm SD ( $n=6$ ), means with different superscript letters within column are significantly different at $p<0.05$ by Duncan's multiple range tests. Captopril was used for control.

Table 3. Inhibition activity of extracts from Aster scaber on xanthine oxidase

\begin{tabular}{ccccccc}
\hline \multirow{2}{*}{\begin{tabular}{c} 
Phenolic concent $(\mu \mathrm{g} / \mathrm{mL})$ \\
\cline { 2 - 7 }
\end{tabular}} & \multicolumn{2}{c}{ Water extracts } & \multicolumn{2}{c}{ Ethanol extracts } & \multicolumn{3}{c}{ Allopurinol } \\
\cline { 2 - 7 } & Uric acid $(\mu \mathrm{g} / \mathrm{mL})$ & Inhibition activity $(\%)$ & Uric acid $(\mu \mathrm{g} / \mathrm{mL})$ & Inhibition activity $(\%)$ & Uric acid $(\mu \mathrm{g} / \mathrm{mL})$ & Inhibition activity $(\%)$ \\
\hline Control & $45.25 \pm 0.12^{1)}$ & - & $45.70 \pm 0.17$ & - & $45.61 \pm 0.24$ & - \\
50 & $4.14 \pm 0.26$ & $90.91 \pm 0.57^{\mathrm{b}}$ & $35.54 \pm 0.31$ & $21.93 \pm 0.68^{\mathrm{a}}$ & $10.03 \pm 0.22$ & $77.97 \pm 0.49^{\mathrm{a}}$ \\
100 & $5.15 \pm 0.95$ & $88.69 \pm 2.10^{\mathrm{ab}}$ & $23.24 \pm 0.40$ & $48.93 \pm 0.88^{\mathrm{b}}$ & $9.23 \pm 0.40$ & $79.73 \pm 0.88^{\mathrm{ab}}$ \\
150 & $6.34 \pm 0.50$ & $86.07 \pm 1.09^{\mathrm{a}}$ & $16.85 \pm 1.29$ & $62.99 \pm 2.83^{\mathrm{c}}$ & $7.83 \pm 0.52$ & $82.80 \pm 1.13^{\mathrm{b}}$ \\
200 & $2.77 \pm 0.50$ & $93.92 \pm 1.09^{\mathrm{c}}$ & $9.02 \pm 0.88$ & $80.19 \pm 1.93^{\mathrm{d}}$ & $4.23 \pm 0.42$ & $90.72 \pm 0.93^{\mathrm{c}}$ \\
\hline
\end{tabular}

${ }^{1)} \mathrm{Mean} \pm \mathrm{SD}(\mathrm{n}=6)$, means with different superscript letters within column are significantly different at $\mathrm{p}<0.05$ by Duncan's multiple range tests. Allopurinol was used for control.

이 가능할 것으로 판단되었다.

참취 추출물의 pancreatin a-amylase 효과

a-Amylase는 탄수화물의 a-D-(1,4)-glucan 결합을 분해 하는 효소(37)로서 소장에서 음식물 중의 전분을 포도당과 같은 단당으로 분해하여 흡수시킨다. 따라서 소장의 a -amylase를 저해함으로써 포도당의 흡수를 지연시킬 수 있 어 a-amylase의 저해활성은 혈당수치 상승억제의 지표로써 사용된다(38). 참취 추출물의 $\mathrm{a}$-amylase 활성저해 효과를 측정한 결과 Table 4에서와 같이 물 추출물에서는 2.0 $23.8 \%$ 의 효소 억제 효과를 나타내었으며, 참취 ethanol 추출 물은 100 200 $\mathrm{\mu g} / \mathrm{mL}$ 의 phenolics 농도에서 대조구로 쓰인

Table 4. Inhibition activity of extracts from Aster scaber on a -amylase

\begin{tabular}{ccccc}
\hline \multirow{2}{*}{ Sample } & \multicolumn{4}{c}{$a$-Amylase inhibition activity (\%) } \\
\cline { 2 - 5 } & \multicolumn{4}{c}{ Phenolic content $(\mu \mathrm{gg} / \mathrm{mL})$} \\
\cline { 2 - 5 } & 50 & 100 & 150 & 200 \\
\hline Water extracts & $2.00 \pm 0.14^{\mathrm{a} 1)}$ & $2.86 \pm 0.27^{\mathrm{a}}$ & $9.71 \pm 0.11^{\mathrm{b}}$ & $23.81 \pm 0.84^{\mathrm{c}}$ \\
Ethanol extracts & $6.67 \pm 0.12^{\mathrm{a}}$ & $48.57 \pm 1.05^{\mathrm{b}}$ & $76.00 \pm 2.12^{\mathrm{c}}$ & $88.57 \pm 0.97^{\mathrm{d}}$ \\
Acarbose & $17.42 \pm 2.31^{\mathrm{a}}$ & $20.33 \pm 1.72^{\mathrm{b}}$ & $26.64 \pm 1.92^{\mathrm{c}}$ & $40.03 \pm 2.31^{\mathrm{d}}$ \\
\hline
\end{tabular}

${ }^{11} \mathrm{Mean} \pm \mathrm{SD}(\mathrm{n}=6$ ), means with different superscript letters within level are significantly different at $p<0.05$ by Duncan's multiple range tests. Acarbose was used for control. acarbose의 20.33 40.03\% 억제효과에 비해 상대적으로 우 수한 48.57 88.57\%의 높은 억제력을 나타내었다. Lee와 Lee(39)는 phenol성 물질은 여러 식물체에 널리 분포되어 있지만 그들의 함량, 종류, 형태 등이 각각 다르므로, $a$ -amylase 효소 활성의 저해는 polyphenol의 양과 종류에 따 라 달라진다고 하였다. 참취의 각각 추출물에 용해되어 있 는 phenolic 화합물 성분과 종류에 따라서 상대적으로 다른 효소 억제력을 보인 것으로 판단되었다.

\section{참취 추출물의 tyrosinase 저해 효과}

흑갈색의 색소 melanin은 피부의 melanocyte 세포에서 펩타이드 tyrosinase에 의해 생성되어진다. Tyrosinase는 인 체내의 melanin 생합성 경로에서 가장 중요한 초기 속도결 정 단계인 L-tyrosine에서 L-DOPA를 거쳐 L-dopaquionone 으로의 전환에 관여하는 효소로서, 피부가 자외선에 노출 되었을 때 활성화되어 피부노화가 촉진되며 피부에 암갈색 의 색소물질을 침착하게 하기 때문에 미백 성분의 효과를 평가하는데 널리 이용되고 있다(40). 참취 추출물의 tyrosinase 저해활성을 측정한 결과 Table 5에서와 같이 대 조구인 kojic acid는 35.21 77.03\%의 억제효과를 나타내었 으나, 참취 ethanol 추출물에서는 13.8 24.7\% 저해활성을 나타내었고, 물 추출물에서는 15.8 46.9\% 저해활성을 나타 내어 미백 효과를 위한 기능성 식품으로 활용하기 위해서는 
물 추출물이 더 효과적이라고 판단되었다. Jo과 $\mathrm{Cho}(35)$ 는 오가피 열매(Acanthopanax fruit) 추출물의 phenolic 화합물 이 $200 \mu \mathrm{g} / \mathrm{mL}$ 의 phenolics 농도에서 물 추출물과 ethanol 추출물이 $33.7 \%, 58.8 \%$ 의 tyrosinase 저해활성을 나타내었 다고 보고한 결과에 비해 조금 낮은 활성을 나타내었다.

Table 5. Inhibition activity of extracts from Aster scaber on tyrosinase

\begin{tabular}{ccccc}
\hline \multirow{2}{*}{ Sample } & \multicolumn{4}{c}{ Tyrosinase inhibition activity (\%) } \\
\cline { 2 - 5 } & 50 & 100 & 150 & 200 \\
\cline { 2 - 5 } & $15.78 \pm 0.57^{\mathrm{a})}$ & $15.62 \pm 0.47^{\mathrm{a}}$ & $24.49 \pm 0.27^{\mathrm{b}}$ & $46.86 \pm 2.83^{\mathrm{c}}$ \\
\hline Water extracts & $13.77 \pm 1.62^{\mathrm{a}}$ & $14.88 \pm 3.59^{\mathrm{a}}$ & $22.85 \pm 0.60^{\mathrm{b}}$ & $24.70 \pm 1.35^{\mathrm{b}}$ \\
Ethanol extracts & $35.21 \pm 2.09^{\mathrm{a}}$ & $55.43 \pm 1.72^{\mathrm{b}}$ & $67.92 \pm 1.32^{\mathrm{c}}$ & $77.03 \pm 1.51^{\mathrm{d}}$ \\
\hline Kojic acid &
\end{tabular}

${ }^{11}$ Mean $\pm S D(n=6)$, means with different superscript letters within level are significantly different at $\mathrm{p}<0.05$ by Duncan's multiple range tests. Kojic acid was used for control.

\section{참취 추출물의 elastase 저해 효과}

Elastase는 피부구조와 탄력을 유지하는 역할을 하는 주 요 단백질 중의 하나인 elastin을 분해하거나 collagen을 비 특이적으로 가수분해하는 효소이다. 피부주름은 연령이 증 가함에 따라 collagen 생성 감소 또는 분해속도 증가, 자외선 등에 의해 elastase 활성이 증가되어 생성되는 것으로 알려 져 있다(27). 참취 추출물의 elastase 저해 활성을 측정한 결과 Table 6에서와 같이 대조구인 epigallocatechin-gallate 는 55.54 73.25\%의 높은 억제효과를 나타내었으나, 참취 ethanol 추출물에서는 물 추출물보다 낮은 활성으로 200 $\mu \mathrm{g} / \mathrm{mL}$ phenolics 농도에서 $14.4 \%$ 의 저해활성을 나타냈고, 물 추출물에서는 $45.5 \%$ 저해활성을 나타내었으며, $\mathrm{Cho}$ 과 Choi(41)는 감태(Eckloina cava) 추출물을 $1 \mathrm{mg} / \mathrm{mL}$ phenolics의 농도로 처리했을 때 $44 \%$ 의 elastase 저해 활성 이 나타난다고 보고한 것과 비교해 참취 추출물의 elastase 저해활성이 더 우수한 것으로 판단하였다.

이상의 결과로 보아 참취 추출물은 우수한 항산화력, 고 혈압억제력, 통풍억제력 등을 활용한 성인병 예방식품에

Table 6. Inhibition activity of extracts from Aster scaber on elastase

\begin{tabular}{|c|c|c|c|c|}
\hline \multirow{3}{*}{ Sample } & \multicolumn{4}{|c|}{ Elastase inhibition activity (\%) } \\
\hline & \multicolumn{4}{|c|}{ Phenolic content $(\mu \mathrm{g} / \mathrm{mL})$} \\
\hline & 50 & 100 & 150 & 200 \\
\hline Water extracts & $23.22 \pm 1.23^{\text {al) }}$ & $35.39 \pm 1.70^{\mathrm{b}}$ & $37.65 \pm 1.88^{b}$ & $45.48 \pm 0.69^{\mathrm{c}}$ \\
\hline Ethanol extracts & $1.13 \pm 1.04^{\mathrm{a}}$ & $8.96 \pm 0.45^{b}$ & $13.30 \pm 1.29^{c}$ & $14.35 \pm 1.18^{\mathrm{c}}$ \\
\hline Epigallocatechin-gallate & $55.54 \pm 2.07^{\mathrm{a}}$ & $62.03 \pm 3.35^{\mathrm{b}}$ & $67.78 \pm 1.46^{\mathrm{bc}}$ & $73.25 \pm 3.03^{c}$ \\
\hline
\end{tabular}

적용이 가능할 것으로 판단되었으며, 미백효과와 주름개선 효과도 있어 미용식품 활성 소재로서 활용 가능성이 큰 것으로 판단되어 노화로 인해 발생하는 신체 내외의 여러 가지 징후들을 예방할 수 있는 anti-aging 소재로 활용이 가능할 것으로 판단되었다.

\section{요 약}

참취로부터 phenolic compounds를 추출 후 항산화 효과, 건강 기능성 식품 및 미용식품 활성을 검정하여 기능성 소재로 활용 가능성을 살펴보았다. 참취에 함유되어 있는 페놀성 물질은 물과 $60 \%$ ethanol을 용매로 하여 추출하였을 때 각각 $11.1 \mathrm{mg} / \mathrm{g}, 4.18 \mathrm{mg} / \mathrm{g}$ 함량을 나타내었다. 추출물의 phenolic 농도를 50 200 $\mathrm{\mu g} / \mathrm{mL}$ 로 조절하여 $\mathrm{DPPH}$ 를 측정한 결과, 물 추출물과 ethanol 추출물 $50 \mu \mathrm{g} / \mathrm{mL}$ phenolics 농도 에서 각각 $87 \%, 91 \%$ 였고, $\mathrm{ABTS}$ radical decolorization도 $50 \mu \mathrm{g} / \mathrm{mL}$ phenolics 농도에서 각각 $99 \%, 99 \%$ 였다. Antioxidant protection factor는 $200 \mathrm{\mu g} / \mathrm{mL}$ phenolics 농도에 서 물 추출물과 ethanol 추출물에서 각각 $1.87 \mathrm{PF}$ 와 2.22 $\mathrm{PF}$ 로 측정되었으며, TBARs값은 $50 \mu \mathrm{g} / \mathrm{mL}$ phenolics농도에 서 물 추출물이 $95 \%$, ethanol 추출물에서 $97 \%$ 를 나타내었 다. Angiotensin converting enzyme(ACE) 저해능은 물 추출 물에서 $50.8 \%$, ethanol 추출물에서 $69.4 \%$ 의 저해율을 나타 내었으며, xanthine oxidase 저해능은 물 추출물은 $50 \mu \mathrm{g} / \mathrm{mL}$ phenolics농도에서 $91 \%$, ethanol 추출물은 $200 \mu \mathrm{g} / \mathrm{mL}$ phenolics농도에서 $80 \%$ 의 높은 효능을 보였다. a-Amylase 저해능은 물 추출물과 ethanol 추출물에서 각각 $24 \%, 89 \%$ 로 ethanol 추출물에서 높은 효능을 보였다. Tyrosinase 저해 능을 측정한 결과 물 추출물과 ethanol 추출물에서 각각 $47 \%, 25 \%$ 의 미백 효과를 나타내었다. Elastase 저해능 측정 결과 물 추출물과 ethanol 추출물에서 각각 $46 \%, 14 \%$ 로 물 추출물에서 주름 개선 효과가 상대적으로 높게 나타내었 다. 이러한 결과로 보아 참취 추출물은 항산화 고혈압억제, 통풍억제, 당분해억제, 미백효과, 주름개선효과 등의 건강 기능성 식품 및 미용식품 활성 소재로서 활용 가능성이 큰 것으로 판단되었다.

\section{References}

1. Choi MS, Yang JK (2008) Industrial potentiality of wild edible greens. J Food Res Technol, 21, 1-7

2. Atoui AK, Manscuri A, Boskou G, Kefalas P (2005) Tea and herbal infusions: Their antioxidant activity and phenolic propolis. Food Chem, 89, 27-36

3. Elzaawely AA, Xuan TD, Tawata S (2005) Antioxidant 
and antibacterial activities of Rumex japonicus HOUTT. Aerial parts. Biol Pharm Bull, 28, 2225-2230

4. Carrasco-Pancorbo A, Cerretani L, Bendini A, SeguraCarretero A, Del-Carlo M, Gallina-Toschi T, Lercker G, Compagnone D, Fernandez-Gutierrez A (2005) Evaluation of the antioxidant capacity of individual phenolic compounds in virgin olive oil. J Agric Food Chem, 53, 8919-8925

5. Perez-Bonilla M, Salido S, Beek TA, Linares-Palomino PJ, Altarejos J, Nogueras M, Sanchez A (2006) Isolation and identification of radical scavengers in olive tree (Olea europaea) wood. J Chromatogr A, 1112, 311-318

6. Valavanidis A, Nisiotou C, Papageorgiou Y, Kremli I, Satravelas N, Zinieris N, Zygalaki H (2004) Comparison of the radical scavenging potential of polar and lipidic fractions of olive oil and other vegetable oils under normal conditions and after thermal treatment. J Agric Food Chem, 52, 2358-2365

7. Lee YS, Joo EY, Kim NW (2005) Antioxidant activity of extracts from the Lespedeza bicolor. Korean J Food Preserv, 12, 75-79

8. Seo SJ, Shim KB, Kim NW (2011) Antioxidant effects of solvent fraction from Nandina domestica fruits. J Korean Soc Food Sci Nutr, 40, 1371-1377

9. Kim JH, Kim MK (1999) Effect of dried leaf powders and ethanol extracts of $\mathrm{p}$ erilla frutescens, artemisia princeps var. orientalis and Aster scaber on lipid metabolism and antioxidative capacity in rats. J Nutr Health, 32, 540-551

10. Han IA (2010) A study on the antibacterial and antioxidative effects of each fraction of Ligularia stenocephala, Ligularia fischeri, and Aster scaber extracts. MS Thesis, Chungnam National University, Korea, p 3

11. Choi NS, Oh SS, Lee JM (2001) Changes of biologically functional compounds and quality properties of Aster scaber (Chamchw) by blanching conditions. Korean J Food Sci Technol, 33, 745-752

12. Lee TB (1999) An Illustrated Book of the Korean Flora. Hangmoonsa, Seoul, Korea, p 739

13. Kim TJ (1996) Korea resources plants IV. Seoul National University Press, Seoul, Korea, p 230

14. Rural Development Administration (RDA) (1997) Illustrated book for emergency plants. National Honam Agricultural Experiment Station, Jeonju, Korea, p 221

15. Lim SS, Lee JH (1997) Effect of Aster scaber and Lxeris dentata on contractility and vasodilation of cardiovascular and endothelial cell in hyperlipidemic rat. J Korean Soc Food Sci Nutr, 26, 300-307

16. Park JR, Park JC, Choi SH (1997) Screening and characterization of anticholesterogenic substances from edible plant extracts. J Korean Soc Food Sci Nutr, 26, 236-241

17. Folin O, Denis W (1912) On phosphotungastic-phosphomolybdic compounds as color reagents. J Biol Chem, 12, 239-243

18. Blios MS (1958) Antioxidant determination by the use of a stable free radical. Nature, 181, 1199-1200

19. Pellegrini N, Re R, Yang M, Rice-Evans C (1999) Screening of dietary carotenoids and carotenoid-rich fruit extracts for antioxidant activities applying 2,2'-azinobis (3-ethylbenzothiazoline-6-sulfonic acid) radical cation decolorization assay. Methods in Enzymology, 299, 379-389

20. Andarwulan N, Shetty K (1999) Phenolic content in differentiated tissue cultures of untransformed and Agrobacterium-transformed roots of anise (Pimpinella anisum L.). J Agric Food Chem, 47, 1776-1780

21. Buege JA, Aust SD (1978) Microsomal lipid peroxidation. Methods in Enzymology, 52, 302-310

22. Cushman DW, Cheung HS (1971) Spectrophotometric assay and properties of the angiotensin-converting enzyme of rabbit lung. Biochemical Pharmacol, 20, 1637 $-1648$

23. Stirpe F, Della-Corte E (1969) The regulation of rat liver xanthine oxidase. J Biol Chem, 244, 3855-3863

24. Davidson PM, Parish ME(1989) Methods for testing the efficacy of food antimicrobials. Food Technol, 43, 148-155

25. Hearing VJ Jr (1987) Mammalian monophenol monooxygenase (Tyrosinase): Purification, properties and reaction catalyzed. Methods in Enzymology, 142, 154-165

26. Kraunsoe JAE, Claridge TDW, Lowe G (1996) Inhibition of human leukocyte and porcine pancreatic elastase by homologues of bovine pancreatic tyrosin inhibitor. Biochemistry, 35, 9090-9096

27. Vinson JA, Su X, Zubik L, Bose P (2001) Phenol antioxidant quantity and quality in Foods: Fruits. J Agric Food Chem, 49, 5315-5321

28. Wang SY, Jiao H (2000) Scavenging capacity of berry crops on superoxide radicals, hydrogen peroxide, hydroxyl radicals, and singlet oxygen. J Agric Food Chem, 48, 5677-5684

29. Kang MJ (2000) Antioxidant activity and free radical 
scavenging effect of dandelion extract. $\mathrm{Ph} \mathrm{D}$ Thesis, Yeungnam University, Korea, p 43-44

30. Kim JS, Lee JY, Park KT, An BJ, Lee SH, Cho YJ (2013) The biological activity from Prunella vulgaris extracts. Korean J Food Preserv, 20, 234-241

31. Venkat Ratnam D, Ankola DD, Bhardwaj V, Sahana DK, Ravi Kumar MNV (2006) Role of antioxidants in prophylaxis and therapy: A pharmaceutical perspective. Journal of Controlled Release, 113, 189-207

32. Sies H (1997) Oxidative stress: oxidants and antioxidants. Exp Physiol, 82, 291-295

33. Kenneth B, Beckman, Bruce NA (1998) The free radical theory of aging matures. physiol Rev, 78, 547-581

34. Cho EK, Song HJ, Cho HE, Kim MH, Choi IS, Choi YJ (2009) Inhibitory effects of ethanol extracts from pine buds (Pinus densiflora) on angiotensin converting enzyme, xanthine oxidase and nitric oxide synthesis. J Life Sci, 19, 1629-1636

35. Jo BS, Cho YJ (2012) Biological activity of extracts from Acanthopanax sessiliflorum fruit. Korean J Food Preserv, 19, 586-593

36. Kim KB, Jo BS, Park HJ, Park KT, An BJ, Ahn DH,
Kim MU, Chae JW, Cho YJ (2012) Healthy functional food properties of phenolic compounds isolated from Ulmus pumila. Korean J Food Preserv, 19, 909-918

37. Lee BB, Park SR, Han CS, Han DY, Park EJ, Park HR, Lee SC (2008) Antioxidant activity and inhibition activity against a-amylase and a-glucosidase of Viola mandshurica extracts. J Korean Soc Food Sci Nutr, 37, 405-409

38. Oh SJ, Hong SS, Kim YH, Koh SC (2008) Screening of biological activities in fern plants native to Jeju island. Korean J Plant Res, 21, 12-18

39. Lee JH, Lee SR (1994) Some physiological activity of phenolic substances in plant foods. Korean J Food Sci Technol, 26, 317-323

40. Tsuji N, Moriwaki S, Suzuki Y, Takema Y, Imokawa G (2001) The role of elastases secreted by fibroblasts in wrinkle formation: implication through selective inhibition of elastase activity. Photochem Photobiol, 74, 283-290

41. Cho EK, Choi YJ (2010) Physiological activities of hot water extracts from Ecklonia cava Kjellman. Journal of Life Science, 20, 1675-1682 